Научный альманах стран Причерноморья. 2019. Том 19. № 3

DOI 10.23947/2414-1143-2019-19-3-61-74

UDK $001+008$

\title{
THE GENESIS OF CAUCASIAN MOUNTAIN CIVILIZATION
}

\author{
(C) Victor V. Chernous \\ South Federal University \\ science-almanac@mail.ru
}

[В.В. Черноус Генезис кавказской горской цивилизации]

\begin{abstract}
Victor V. Chernous (1949-2018) - Ph.D. in Politics, Professor, South Federal University, Rostov-on-Don, Russian Federation.

Черноус Виктор Владимирович (1949-2018) - кандидат политических наук, профессор, Южный федеральный университет, г. Ростов-на-Дону, Российская Федерация.
\end{abstract}

In modern historical and ethnological disciplines, a methodological situation has developed, "which is characterized by the fact that historical knowledge turns into a cognitive field of diverse opinions and disparate intertextual" language games ", and historical reality dissolves in many individual semantic worlds and meanings."

The above fully applies to Caucasian studies, the methodological crisis of which is complicated by the politicization of humanitarian knowledge, attempts to bring the historical culturological foundation to geopolitical projects and the corresponding construction of new identities.

Even within the framework of the formational approach that reigned supreme in Soviet science, scientists encountered a number of complex methodological problems when studying the Caucasus. The Caucasus was considered as a complex structured historical and ethnographic province, divided into the Caucasus (South Caucasus) and the North Caucasus cultural region and Dagestan close to it, both from the point of view of the geographical environment and, above all, the manifestation of formation models here. Despite the debatability of individual problems, the history of Azerbaijan, Armenia, and Georgia completely fit into the theory of socio-economic formations accepted in Soviet science. As applied to the history of the peoples of the North Caucasus and Dagestan, a unified approach to determining the typology and level of development of mountain and nomadic societies before joining Russia could not be developed.

Even within the framework of the formational approach that reigned supreme in Soviet science, scientists encountered a number of complex methodological problems when studying the Caucasus. The Caucasus was considered as a complex structured historical and ethnographic province, divided into the Caucasus (South Caucasus) and the North Caucasus cultural region and Dagestan close to it, both from the point of view of the geographical environment and, above all, the manifestation of formation models here. Despite the debatability of individual problems, the history of Azerbaijan, Armenia, and Georgia completely fit into the theory of socio-economic formations accepted in Soviet science. As applied to the history of the peoples of the North Caucasus and Dagestan, a unified approach to determining the typology and level of development of mountain and nomadic societies before joining Russia could not be developed. 
The mountaineers qualified social relations as tribal, feudal-slaveholding, semi-feudalsemi-patriarchal, and early feudal and developed feudal, etc. As rightly noted Ossetian historian F.Kh. Gutnov, a characteristic of the social structure of the mountain peoples was given in many works from the opposite: feudal, because not slaveholding, patriarchal, because not feudal, etc.

The concept of "mountain feudalism" by Georgian historians did not solve the problem (G. A. Melikishvili, supported by 3. V. Anchabadze, A. I. Robakidze, R. L. Kharadze, G. D. Togoshvili, etc.). The static nature of the proposed model and its features (lack of feudal ownership of land, etc.) did not allow most Caucasian scholars to support the theoretical research of Georgian scientists, although they gave impetus to further research and the search for a form of Caucasian identity.

The deadlock of attempts to adjust the original relations of the mountain peoples of the Caucasus to the stereotypes and cliches developed on the basis of the study of Western European and Russian history was pointed out in one of his articles by A.P. Pronshtein.

In the 90s, the first steps of applying a civilizational approach to the history of the Caucasus were identified while maintaining the system analysis characteristic of research within the framework of the formation methodology. V.V. Chernous (1992) raised the issue of highlighting the Caucasian mountain civilization. T.U. Ktsoeva (1994), R.G. Abdulatipov (1995) and other ideologists of the "Caucasian House" substantiated the phenomenon of a unified Caucasian civilization.

Since then, for about ten years there has been a discussion about the applicability of the civilizational approach to Caucasian studies. Various approaches are proposed: the variational concepts of a unified Caucasian civilization (more precisely, a single cultural-historical type) are justified - A.Y. Shadzhe, O.N. Domenia, Kh.G. Tkhagapsoyev et al., North Caucasian civilization (A.A. Anikeev and some other Stavropol authors), independent civilizations of closely related peoples: Dagestan (M.R. Gasanov and others), Adyghe (A.Kh. Bizhev, A.Sh. Bakiev etc.) and others.

In my opinion, each civilizational version has a right to exist and allows, by making various cognitive accents, highlight new sides of the region's complex historical and cultural development. Correlation of theoretical and methodological approaches, unification of the conceptual apparatus is necessary, without which the civilizational paradigm will remain "speculative and unspecific" (1998). Recently, substantial works have appeared that began to change the historiographic situation, form the problem field of the civilizational approach, but V.Kh. Akayev, however, retains its strength.

In my opinion, the methodology developed in the framework of the theory of local civilizations, which recognizes the polycentricity of the world-historical process, is quite applicable to the study of the Caucasus. Given the polyphonic nature of the concept of civilization, I will explain my position. By civilization we mean a developing, but stable in its basic typological features and archetypes, spiritual, socio-cultural and economic ethno-religious complex. Its backbone factors: religious-moral worldview, system of existential values and taboo, symbolic space, natural-landscape conditions and ways of managing, forms of state-political organization, self-government, legal relations and ways of sociocultural communication. Historically, these factors are manifested in a specific space-time framework uniquely, in different ways; they receive a different hierarchy, which is expressed in the birth and development of distinctive local civilizations. The individuality of civilizations consists, first, in the peculiarities of thinking, perception of the environment, reality, ways of displaying it, in value priorities and social practice.

From this point of view, we can talk about humanity at all stages of its development as a complex, but striving for the integrity of the supraorganic system. Its subsystems are rela- 
tively independent regional and trans-regional civilizations, which at each moment of historical development are at asynchronous stages. This gives a systemic, but not unitary planetary civilization, to the uncertainty of functioning and multivariate development. In this system, one can distinguish the focal traditional mountain civilization. Researchers have repeatedly pointed out the common features in the civilizational and cultural development of mountain peoples in different parts of the globe since the time of F. Ratzel. The actualization of the problem in recent years is associated with the methodological search of Caucasian scholars, the works of Kh. A. Nukhaev in line with Hanafi and Chechen traditionalism.

For all the ambivalence of the "civilization" category, not a single version of the civilizational approach in relation to the Caucasus, in contrast to the geopolitical paradigm, allows us to conceptualize, in our opinion, it as a single civilization.

The North Caucasus is a part of the Caucasian historical and ethnographic region. It is separated from Transcaucasus by the Glavny (or Dividing) Range of the Greater Caucasus, which is the main factor determining significant differences in the climate of the North Caucasus and Transcaucasia. It blocks the masses of cold Arctic air from entering the Transcaucasus and delays the advance to the North of the flows of warm Mediterranean air from the Black Sea. As a result, the North Caucasus and Transcaucasia have significant differences in natural landscape conditions, which ultimately affects the characteristics of economic activity, culture, and the forms of socio-political life of the peoples of the Caucasus.

The natural conditions of the mountainous Caucasus are subject to the law of vertical zoning. As the topography increases, the climate on the southern slopes of the Greater Caucasus changes from subtropical to moderately warm and then to cold, right down to the belt of eternal snows and ice. Accordingly, in the foothills and plains of the North Caucasus there is a zone of broad-leaved forests, above is a zone of coniferous forests, and even higher - subalpine and alpine meadows. The vegetation cover of the North Caucasus represents two types of landscape zonality: West Caucasus and East Caucasus, the latter includes steppe and foothill areas of Dagestan.

\section{Paleocaucasian ethnocultural community}

The North Caucasus is one of the areas of primary settlement of the territory of Russia by an ancient person. Paleoanthropological findings in Transcaucasia (Georgia) even allow the Caucasus to be included in the ancestral home of mankind, at least in the area of sapientation, i.e. the formation of man of a modern kind. Archaeological studies of recent decades attribute the process of settlement of the North Caucasus to the Achelian era of the Lower Paleolithic (500-300 thousand years ago), i.e. to the pre-Neanderthal stage. The main Acheulean monuments are concentrated in the Kuban region and the Northern Black Sea region. Nevertheless, the question of the initial ${ }^{\mathrm{TM}}$ residence, the time of the appearance of people in the North Caucasus remains unclear. It is assumed that the Caucasus was populated from the territories directly bordering it, the uplands of Western Asia. In any case, the integrated use of data from archeology, anthropology, onomastics, toponymy and other scientific disciplines proves the undoubted connections of the ancient cultures of the Caucasus and Western Asia.

Two main routes of migration of ancient people from the Near East to the Caucasus are revealed: the East through the Lesser Caucasus and Central Transcaucasia towards the Caspian and the West through Anatolia to the Black Sea. Both ways led around the Main Range and its spurs to the North Caucasus.

The process of development of ancient man proceeded through the Neanderthal stage to the nonanthropus within the entire North Caucasus. The sequence of development of material culture reflects the constancy of human habitation in the Caucasus. Ancient people lived in inaccessible gorges and foothills of the North Caucasus. In subsequent times, they 
encountered migration flows that bypassed the Main Caucasian Range, as well as from the steppes of Southeastern Europe. In the Caucasus, "the interaction of aliens with Aborigines constitutes the content of ethnic history at its various stages."

The Caucasus was one of the most important centers of genesis of races. The physical type, unlike other characteristics of human communities, is subject to biological heredity and is not causally related to historical, cultural, linguistic and ethnic processes under the influence of which all ethnic characteristics can change without exception. A study of the anthropological characteristics of the population of the Caucasus leads scientists to the conclusion that in the Bronze Age the Mediterranean type was dominant with Caucasian features that had formed by then. The main characteristic features of this type: a sharp expression of dolichocrania, a high arch of the cerebral box, a narrower and higher middle face, a high nose, a sharply protruding nose, etc. The population of the Caucasus at that time was part of the formation of the European, more precisely, South Caucasian race and regionally occupied part of this area.

The common Caucasian unity of archaeological cultures, the anthropological kinship of peoples gives reason to assume the presence of a Caucasian substrate in the Stone Age, which formed the basis for the formation of the Caucasian language family. Caucasian linguistic unity was probably formed in the first half of the Upper Paleolithic. The hypothesis of genetic relationship between the autochthonous languages of the Caucasus was first formulated in the middle of the $19^{\text {th }}$ century by P.K. Uslarom. Between Caucasian languages, lexical, syntactic, morphological and phonetic communities are revealed. G.A. Klimov, G.V. Tsereteli, T.V. Gamkrelidze and some other authors believe that this community is not necessarily genetic, its occurrence under the influence of a substrate or as a result of prolonged contact is not excluded.

In recent decades, the theory of a common Iberian-Caucasian language has been called into question. Linguistic studies have shown significant differences between the Kartvelian (Georgian) languages from the Nakhodagestan and Abkhaz-Adyghe language groups. In accordance with these studies, the Kartvelian languages were included in the Nostratic macro-family, and the Nakhodagestan and Abkhaz-Adyghe were combined into the North Caucasian language family, which constituted the branch of the Sino-Caucasian macro-family. Most researchers A.S. Chikobava, Yu.D. Desheriev, U.A. Meylanova and others, however, believe that the community of languages of the Iberian-Caucasian family, taking into account anthropological, archaeological and ethnographic data, is proved from the early stages of development, which makes it impossible to study the scientific history of any language group without taking into account data from other groups.

An important role in the ethnocultural history of the North Caucasus was played by the Neolithic revolution. In the $7^{\text {th }}-5^{\text {th }}$ millennium $B C$, people pass from the appropriating economy (gathering, hunting, fishing) to the producing economy (the rudiments of agriculture, domestication of animals, pottery, grinding of stone tools, etc.). As a result, conditions are created for a more stable food supply and population growth. The tribes crushed, and migration began in search of new territories. In this case, both ancient and new ways were used. The tribes of the Western Caucasus made up a kind of unified ethnocultural region with the southern part of Asia Minor, had cultural and economic ties with the ancient civilizations of Mesopotamia, Asia Minor, and the Eastern Mediterranean. At the same time, the ties were intensifying between the autochthonous population of the steppe Ciscaucasia and the steppe population of Southeastern Europe i.e. the Volga-Don interfluve. 
The origins of the collapse of cultural Caucasian and linguistic unity probably go back to the Mesolithi, an era transitional from Paleolithic to Neolithic. The collapse of the PaleoCaucasian ethnocultural community was facilitated by the physical and geographical relief of the Caucasus. In the $4^{\text {th }}-3^{\text {rd }}$ millennium BC, it broke up into three ethnic communities - the western (Abkhaz-Adyghe), eastern (Nakh-Dagestan) and southern (Kartvelian).

In the Eneolithic and Bronze Age, bright and distinctive agricultural-cattle-breeding type cultures emerge on the territory of the North Caucasus, and the Western and East Caucasian languages are further developed and separated. At the same time, migration processes were of considerable importance, when the population of the North Caucasus becomes involved in the processes of ethnic and anthropological integration with different immigrant groups.

Ethnogenetic processes are among the most difficult problems of ethnology, archeology, and historical science. In national science, problems of ethnic history, including the ethnogenesis of the peoples of the North Caucasus, traditionally occupy an important place. In the post-Soviet period, these searches turned out to be simplified and vulgarized for the sake of one or another modern, usually nationalistic, political goal. They manifest themselves in a conscious or unconscious desire to idealize the historical role of their peoples, instilling in them a sense of national exclusiveness. The authors of this direction are trying to prove that their peoples are purebred in origin, the oldest in Eurasia and participated in the creation of the most ancient civilizations. At the same time, the idea "of a straightforward ethnolinguistic kinship of certain North Caucasian peoples with famous ancient peoples (Sumerians, Hutts, Hurito-Urartians, Indo-Aryans and Indo-Iranians, Etruscans, etc.), as well as with the tribes-creators of a number of North Caucasian archaeological cultures (Maykop, Koban, Alan). Moreover, representatives of different republics of the region often claim such kinship with some of these ancient ethnic groups." Meanwhile, ethnic history develops in complex and contradictory ways. Archaeological cultures are determined almost exclusively on the basis of the remnants of material culture and cannot fully be considered the equivalent of any one ethnic group, which is abused by individual domestic (naturally, not only North Caucasian) scholars and especially amateurs. The ethnic history of any nation, along with the problem of the origin of the ethnic group, includes interethnic contacts and interactions, and long ethnic isolation is extremely rare and is an anomaly. Ethnic history includes the migration of peoples, the mixing of peoples as a result of inter-ethnic settlement and the mass conclusion of interethnic marriages, the integration of several ethnic groups into one or the differentiation of one ethnic group into two or more, numerical growth and reduction, integration and assimilation processes, etc. At different periods of their ethnic history, the peoples of the North Caucasus experienced processes of consolidation (the merging of language and culture-related tribes and nationalities), assimilation (dissolution of the ethnic groups of one people in another) and integration (linguistic and cultural relations of ethnic groups, as a result of which common features of culture). Therefore, "pure" autochthonous peoples, as well as "pure" migrants, practically do not exist. In the ethnogenesis of each nation, autochthonous traits (substrate) are combined with traits of a newcomer population in the form of layering (superstratum) or inclusion (adstratum) - elements of language, culture, etc.

From the first half of the fourth millennium BC in the Caucasus began to use metal. The beginning of the Bronze Age in the North Caucasus coincided with the formation of nomadic cattle-breeding communities in the steppes of Eurasia. Relations with nomads were characterized by both a peaceful process of diversified mutual influence, exchange ties, and 
invasions of the steppes on the territory of the North Caucasus. These relationships were decisive for the ethnocultural and political development of the population of the North Caucasus, throughout the Bronze Age ( $3^{\text {rd }}-1^{\text {st }}$ millennium BC). In the early Bronze Age, Iranianspeaking aliens from the steppe spaces of the north assimilated into the ethnic environment of the local population. It reflected in some changes in material culture, funeral rites, etc.

At the beginning of the Bronze Age, economic and ethnocultural demarcation of various regions of the North Caucasus became more distinct.

In the middle and second half of $3^{\text {rd }}$ millennium BC, Maikop tribes (North-West and Central part of the North Caucasus) and Kuro-Arak culture (North-East Caucasus) are distinguished. Currently, the term "Maykop archaeological culture" unites various monuments, but although there is a tendency to distinguish groups of monuments that differ in specific features from it, the tradition of using it in science is preserved. The basis of the economy of the Maykop tribes was cattle breeding, their achievement was a high level of development of metalworking and pottery production, fabric production. For over a thousand years, the Caucasus has been the main source of metal in the neighboring regions of Eastern Europe. Maykop culture was formed and developed on a local basis, but was significantly influenced by the cultures of Western Asia. She finds numerous analogies in the ancient monuments of the Middle East. The religious representations of the Maykop tribes are associated with the astral cult and overlap with various archaic cults of Transcaucasia and Western Asia.

The tribes of Maykop culture developed in close connection with the tribes of the Yamnaya culture of the steppes of southeastern Europe, Kuro-Arak culture, dolmen culture of the Western Caucasus. The southeastern neighbors of the Maykopians were tribes of the Kuro-Araks culture, connected with Transcaucasia and widespread in North-West Iran, as well as in the Eastern Mediterranean, Syria and Palestine. The basis of the settled life of these tribes was agriculture and cattle breeding: the formation of terraced farming and distant cattle breeding is taking place. Developed were metalworking and pottery. Religious ideas were associated with agriculture and cattle breeding. The leading deity was the goddess of fertility; there were cults of the sun, fire, home.

In the Middle Bronze Age in the mountain-forest regions of the Black Sea, dolmen culture (monumental tombs made of stone slabs and blocks or carved in a rock massif) develops near the ancestors of the Abkhaz-Adygs. These were tribes engaged in agriculture and cattle breeding, as well as marine fishing. The appearance of dolmens in the Caucasus is associated with the distant maritime ties of the West Caucasian peoples (Portugal, Sardinia), as well as with Asia Minor or migrations from Central Europe.

Dolmen culture was in contact with the North Caucasus ( $2^{\text {nd }}$ millennium BC), which was connected with the Maikop and spread to the steppes in the north, the foothills of Dagestan in the east and the Main Caucasian Range in the south. The basis of the economy continued to be livestock and agriculture, metallurgy and metalworking. Within the framework of the North Caucasian culture, local differences in material and spiritual cultures are noted, which probably characterizes the compact residence of kindred tribes in the territory of modern Kuban,

Stavropol, Kabardino-Balkaria, North Ossetia and Chechnya. The weakening of ties with Western Asia, as well as the integration of the less socially developed steppe tribes led to a retardation of development compared to the time of the Maikop culture.

Catacomb culture occupied a vast territory of the steppes, from the Volga to the Dnieper. The tribes of catacomb culture spread in the steppes cultural achievements that were accumulated by Caucasian tribes who communicated with the centers of ancient Eastern 
civilizations. A major role in this was played by wheeled vehicles. By their physical type, people of the catacomb culture are neither the descendants of their predecessors in the steppes of the tribal culture, nor the ancestors of the tribal culture tribes who replaced them. They stood closest to the tribes of the North Caucasus.

To a much lesser extent, the movements of the steppe tribes of Southeast Europe affected the mountainous regions of the North-East Caucasus. An original culture of the local population developed in the mountains of Dagestan and Chechnya. Genetically, it was associated with the North Caucasian version of the Kuro-Araks culture. The population of mountain Chechnya and Dagestan had close ties with the tribes of the adjacent regions of the Caucasus.

From the middle of $2^{\text {nd }}$ millennium BC, in the North-East Caucasus, a KayakentKhorochoev culture is taking shape. Its carriers continue to develop the same sectors of the economy as in the previous period. Significant development is given to horse breeding.

In the Late Bronze Age (late $2^{\text {nd }}-1^{\text {st }}$ millennium BC), new archaeological cultures of the North Caucasus, having common features, arise in the North Caucasus. Koban culture covered the mountainous regions of the central Caucasus and the northern slopes of the foothills of the Central and partially North-Eastern Caucasus. Carriers of the Koban culture of the heyday $\left(9^{\text {th }}-8^{\text {th }}\right.$ centuries $\left.B C\right)$ are characterized by strong settled way of life, their carriers occupied naturally fortified hills. In the east, the Kobanians came into contact with the descendants of the carriers of the Kayakent-Khorochevsky culture. At the beginning of $1^{\text {st }}$ millennium BC, the first samples of iron weapons appeared in the North Caucasus, which gave impetus to the further development of local cultures. Cultural ties, including with remote areas. The appearance of strongholds on fortified settlements, a sharp increase in the number of weapons, and the appearance of burial-rich stocks indicated the formation of societies corresponding to the stage of "military democracy".

A close Koban culture is the Kuban culture (end of $2^{\text {nd }}-1^{\text {st }}$ thousand $B C$ ) in the NorthWest Caucasus. The tribes of the Kuban region were on the path of the transit of material and spiritual culture of the North Caucasus and eastern cultures. They facilitated penetration into the mountainous regions, as well as far into the Northeast Caucasus, from Eastern and Central Europe. In turn, through the Kuban region, North Caucasian objects spread to the west.

Intensification of tribal relations led to the retraction of the North Caucasian tribes of the turn of the $2^{\text {nd }}-1^{\text {st }}$ millennium BC into the general process of movement of peoples. The first inhabitants of the Northern Black Sea Region, whose name was preserved thanks to written sources (Assyro-Babylonian and Greek), were the Cimmerians ("Gimirri").

$6^{\text {th }}$ century BC is the time of the ancient Greek colonization of the Northern Black Sea region. Ancient authors mention over 30 Greek cities and emporia that appeared at different times, the most significant of which were Panticapaeum and Phanagoria. In the $5^{\text {th }}$ century. $\mathrm{BC}$, cities located on the shores of the Cimmerian Bosporus united into the Bosporus kingdom, which subjugated the Scythian-Meotian tribes. On the territory of the Sinds, the largest cities existed i.e. Fanagoria, Kepy, Hermonass. According to a number of researchers, under the influence of the Bosporus, the Sindh state arises among the Sinds. As a result of close economic and political interaction, the cultural interaction of the Greeks and the SindoMeots is taking shape: the spread of imported things, the borrowing of urban planning techniques, the syncretization of religious cults, and the borrowing of mythological subjects.

The Meotians who resettled in the Trans-Kuban region and partially assimilated Sarmatians, together with the Meotians and tribes of the Zikh Union of the Black Sea coast that 
previously lived here, laid the foundations for the formation of a powerful Adyghe ethnic community.

Throughout history, the North Caucasus has connected front Asia with the Black Sea steppes and all of Southeastern Europe as a kind of bridge. Since the early metal era, the population of the North Caucasus has established cultural, economic, and military-political ties with the peoples of the eastern most ancient civilizations, and from the $2^{\text {nd }}$ millennium $\mathrm{BC}$ with tribes of the European Southeast. From $8^{\text {th }}-7^{\text {th }}$ century BC and until the late Middle Ages, the territory of the North Caucasus served as a kind of historical corridor along which various peoples passed. In the $8^{\text {th }}$ century $\mathrm{BC}$, powerful waves of the Cimmerians passed through the North Caucasus and in the $7^{\text {th }}-6^{\text {th }}$ centuries Scythian Iranian-speaking tribes. At the same time, the ancient Greek colonization of the Northern and Eastern Black Sea coast begins. In the $3^{\text {rd }}-1^{\text {st }}$ centuries BC, waves of Iranian-speaking Sarmatians and Alans swept through the North Caucasus, causing significant migration of the local population. Biological mixing, Iranization of culture touched the ancestors of the Circassians, Ossetians, Karachais and Balkars.

In the Late Antique time, morphological differences of the anthropological type, characteristic of the population of Transcaucasia and the North Caucasus, take shape. Comparison of paleontropological materials indicates that the population of Armenia, Iberia and Albania belonged to a single anthropological type or were morphologically very closely related anthropological types, which are combined in the racial systematics by the Mediterranean anthropological type. The population of the North Caucasus, showing genetic continuity with the population of the previous period, refers to a completely different anthropological type, in which Caucasian forms of the Near Asian type prevail, as well as the Adyghe variant of the Pontic type. In Dagestan at that time, similar to Transcaucasian anthropological forms were widespread and some signs characteristic of the population of the North Caucasus were noted only in the form of penetration or infiltration.

From the 4th century $A D$, important changes in the ethnic map of the region began to cause Turkic-speaking peoples who came here - the Huns, Bulgarians, Khazars, etc., which leads to the Turkization of some regions of the North Caucasus. In this difficult ethnopolitical situation, the formation of the modern peoples of the North Caucasus took place, which entailed serious changes in the ethnic map of the region, restrained political genesis and statist tendencies.

The important strategic and commercial position of the Caucasus from ancient times placed it at the center of the struggle between Ancient Greece and the Persian Empire, Rome and the Bosporus kingdom, the Sassanids; Arab Caliphate, Khazar Kaganate and Byzantine Empire.

In the 70 s of the 4th century, a massive invasion of the Caucasus begins, Eastern Europe of the Huns. They devastated the Caspian and Ciscaucasia steppes to the lower reaches of the Don and subjugated the Alans occupying these territories. Pursuing the Alanian tribes, the Huns advanced to the Northern Black Sea coast and to the North Caucasus to the Terek, Kuban, and then to the Taman Peninsula. At the end of 4th-5th centuries, the Huns and other nomads associated with them made devastating campaigns through the North Caucasus to Transcaucasia and Front Asia.

Because of these campaigns, the ancient cities of the North-Eastern Black Sea coast were destroyed, the Bosporus kingdom, many settlements were destroyed, the population was exterminated. The Hun invasion undermined the political role of the Meots and Alans, 
the tribes of Dagestan, stimulated migration processes, and slowed down the cultural development of the peoples of the North Caucasus. In addition, many of them were drawn into the war of the Huns with Iran and Byzantium, state entities of Transcaucasia.

In the 5th century, the Hunnic tribal union broke up, and new diverse tribal unions began to arise and break up, which they continued to refer to as Huns in the sources. In the 6th-7th centuries, they played a significant role in the North-East of the Caucasus. At the same time, other Turkic-speaking unions of tribes emerge in the North Caucasus: Bulgarians, Utiguts and Kutriguts, Savirs, Avars, Turks. Many peoples of the North Caucasus were drawn into their hostilities. By the 6th century, these short-lived unions broke up, and their population settled in the North Caucasus, which was reflected in the peculiarities of the socio-economic and cultural development of the region and the Turkization of individual tribes and ethnic groups. In the 5th-6th century, the politics of the Byzantine Empire and the Sassanian Iran in the Caucasus became more active. Both empires sought to extend their influence to the North Caucasus, as a source of human and food reserves, and involved tribal unions of the Caucasus in the sphere of Eurasian politics. Zikhi and the Western Alan group (the upper Kuban and Foothills) adhered to the Byzantine orientation. The Byzantines spread Christianity to the North-West Caucasus (mainly to the top of the Black Sea tribes), as well as the Hun tribes that lived in the Black Sea Dagestan, but its influence was fragile. Iran spread its influence mainly to the eastern Alans and southern Dagestan. The Shahs sought to spread Zoroastrianism to these tribes, and turned Derbent with the help of local residents into a large military-strategic, political, cultural and economic center of the Caucasus. In the eastern Caucasus, Pahlavi writing is developing. The Byzantine Empire, having entered into an alliance with the West Turkic Kaganate, significantly supplanted Iran in the Caucasus. The constant wars led to the displacement of the Caucasian segment of the Great Silk Road in the north to the Stavropol Upland and the Kuban Valley.

The appearance of the Bulgars in the North Caucasus, which probably were part of the Hunnish horde, is associated with the Hun invasion. In the middle of I millennium AD they occupied the steppes of the Ciscaucasia, including the lower Don region. In the 6th century, Bulgars and part of the local autochthonous population create the tribal association Great Bulgaria. Bulgars in 6th centuary they become dependent on the Avars for a short time (5060 years of the 6th century), and then the Turkic Kaganate (70s of the 6th century). The liberation of the Great Bulgarian Kaganate from power was connected with the help of Byzantium, which contributed to the unification of the Bulgarian tribes under the authority of the baptized Organ, and then his nephew Kubrat. After the death of Kubrat, strife, civil wars with ethnically related Khazars begin, and part of the Bulgars headed by Khan Aspahur goes to the Danube (merging with the South Slavic population they create the Danube Bulgaria), and the other to the Volga, where the Volga Bulgaria led by Khan Batbay remained in Priazov and possibly took part in the ethnogenesis of modern Karachais and Balkars. Bulgars of the North Caucasus entered the 7th century the successor of the Turkic Khaganate - the Khazar Khaganate, which lasted more than three centuries.

In the 7th century. The Zikh tribal union united the Black Sea Adyghe tribes by stimulating the processes of consolidation and assimilation among them and supplanted the GothTetrakists. To the north of the Zikhs, the Kasozh tribal union appears, and in the southeast the Abazg one.

The central part of the North Caucasus in the 2 nd half of the 1 st millennium AD, was occupied by the Nakh tribes (durdzuki, cysts, etc.), the ancestors of the Chechens and Ingush, as well as the Alanian tribes, from which the ethnic basis of the Ossetians (Ovsy) is 
formed as a result of the assimilation processes of the autochthonous population and Iranian aliens. The Alanian Union united not only the Alans proper, but also many tribes of the Caucasus, which were drawn into the confrontation of the Byzantine Empire and Sassanid Iran.

In the 7th-9th centuries, the Alans were in the sphere of influence of the Khazar Kaganate or were subordinate to it. Political associations are forming in Dagestan, covering the territory of the main local tribes and ethnic groups (Lakz, Tabasaran, Serir, Zirikhgeran, Kaitag, Gumik, etc.).

The most important factor in the ethnocultural processes in the North Caucasus were the Arab-Khazar wars. In 643-644, the first clash between the forces of the Arab caliphate and the Khazars took place, which laid the foundation for a long struggle for supremacy in the Caucasus until the 9th century, when the peoples of the North Caucasus were gradually liberated from the power of the kaganate and caliphate. Despite the devastating raids of nomads, the struggle in the North Caucasus between the Byzantine Empire, Sassanid Iran, the Khazar Khaganate and the Arab Caliphate, and other aggressors, the culture of sedentary and nomadic tribes of the North Caucasus continues to rise based on a synthesis of ancient autochthonous tribes with alien culture, and through them with distant and close cultures and civilizations. Relations with the peoples of Transcaucasia, the Middle East, Central Asia, and Southeast Europe underlie the fact that the achievements of world culture were made known to the peoples of the North Caucasus. Three monotheistic religions are spreading in the North Caucasus: Christianity, Islam, and Judaism, the interaction of which with local pagan cults creates a complex syncretic religious worldview among the tribes of the North Caucasus. Sources paint a picture of the wide exchange of cultural values, the spread of the Nart epic, other ethnic and folklore plots, linguistic interaction, common features in the material culture of the peoples of the North Caucasus. The mountain regions of this period appear as areas of developed agriculture, densely populated, with strong fortifications, around which stable ethnopolitical formations formed.

The onslaught of great empires and the problem of maintaining ethnocultural identity, the formation of the Caucasian mountain civilization

In the $10^{\text {th }}$ century, a relative stabilization of political life in the North Caucasus sets in. By this time, relations were being established for part of the tribes of the North Caucasus with the East Slavic tribes and Russia. The Arab-Persian sources of the 10-11th centuries contain information about Ruses - mercenaries (gulems), who served in the service of various Caucasian rulers, as well as about the Ruses' campaigns in the Caucasus, their participation in local feuds. In turn, in the emerging aristocracy of Kievan Rus, a certain role was played by the Alans, Adyghe and Turks.

An important role in all areas of relations between Russia and the peoples of the North Caucasus was played by the Principality of Tmutarakan, located on the Taman Peninsula, Eastern Crimea and, possibly, in the lower Kuban ( $11^{\text {th }}$ century). The population of the principality was multi-ethnic: Ruses, Kasogi, Khazars, Greeks, Armenians.

At the same time, the influx of Turkic tribes in the Ciscaucasia continues: the Pechenegs, and in the middle $11^{\text {th }}$ century Kypchaks (Polovtsy), under the blows of which the Principality of Tmutarakan disintegrated. The Kipchaks ousted the Pechenegs from the Ciscaucasia and reached the plains of Chechnya and Ingushetia, the coastal Dagestan, and took part in the ethnogenesis of the Karachais and Balkars.

In the $10^{\text {th }}-11^{\text {th }}$ centuries, the ethnocultural development of the North Caucasus was most determined by Alania, Georgia and the Kipchaks. 
The North Caucasus partially entered the Muslim "circle of the world cultural community" (V.V. Bartold), but at the same time retained its civilizational and cultural identity. The mutual exchange of material and spiritual values with a more developed Arab-Muslim civilization awakened their own potentials in local cultures, brought to life new intellectual needs and creative opportunities.

In the $16^{\text {th }}-17^{\text {th }}$ centuries, large ethnopolitical associations are taking shape, the foundations of which were laid in the previous time, and they are consolidating in the nationality. At the same time, because of internal strife and civil strife, Crimean-Ottoman aggression, mass migrations of Kabardians, Ossetians, Chechen and Ingush societies, Karachais, part of the population of South Dagestan (Tsakhurs, Avars, etc.) take place, which was associated with the specification of their forms agricultural cattle breeding.

As throughout history, the peoples of the North Caucasus maintained close relations with each other. In many settlements there was a mixed population, the territorial borders were not clearly defined, because peoples lived in stripes, population migrations often occurred, despite frequent civil strife, raids, slave trade, good-neighborliness prevailed in relations between the peoples of the North Caucasus, which manifested itself in widespread consecrated friendship (kunachestvo), fosterage (atalychestvo), the emergence of family ties. All peoples of the North Caucasus have clans, surnames, the ancestors of which were representatives of other peoples.

In the $16^{\text {th }}-17^{\text {th }}$ centuries, Kabarda and Shamkhalate dominated in the North Caucasus, which controlled considerable territories and fought, relying on allies with each other. However, even between them there were wide peaceful political contacts. Interpenetration, dialogue are manifested in all areas of the material and spiritual culture of the peoples of the North Caucasus. The development of two and multilingualism, mutually enriched vocabulary of languages. Turkic languages acquire great influence, and a number of political entities of Dagestan and Chechnya used the Kumyk language for diplomatic correspondence.

The aforementioned allows us to talk about the development of the Caucasian mountain civilization in the North Caucasus in the $16^{\text {th }}-17^{\text {th }}$ centuries.

In the context of our understanding of the "civilization" category, Caucasian mountain civilization is defined by multi-ethnicity, religious syncretism (a synthesis of local paganism with elements of Christianity and various Islamic trends), a single symbolic space, a combination of highlands, foothills and plains, which determines the relationship between terrace farming, alpine cattle breeding and equestrianism, enshrined in peculiar ethical mountain codes, psychological traits, the prevalence of non-state forms of self-organization nation. The conclusion of H.G. Tkhagapsoev about the dominance in the Caucasus of the lectonic type of communication (normatively strictly regulated and ritualized), but we do not share his idea of it as the main civilizational line of the Caucasus. The Caucasian mountain civilization was strongly influenced by Islamic civilization (Iran, the Ottoman Empire), which created the prerequisites for its assimilation by the Muslim world.

By this time, the policy of the Russian (Moscow) state was activated in the Caucasus. Russian civilization in its typological features and system-forming factors differed from the Caucasian mountain civilization and North Caucasian culture. Russian civilization is determined by the Orthodox type of spirituality and existential values, plain natural and landscape conditions with a relatively harsh climate, communal collective forms of economic activity in the conditions of a mobilization type of development, statehood as a dominant form of national self-organization, a legal culture that does not absolutize a formal law. 
In the $16^{\text {th }}-17^{\text {th }}$ centuries, the development of the North Caucasus was increasingly determined by the dialogue of two civilizations, which was generally mutually enriching, mostly acquaintance, expressed in union-vassal relations and in the gradual increase in the pro-Russian orientation of the owners and free societies of the North Caucasus. In subsequent centuries, their relationship will survive the aggravation and civilizational-cultural conflict in the form of the Caucasian war of the $19^{\text {th }}$ century, the collapse of the Caucasian mountain civilization and the adaptation of its segments to the Russian sociocultural system.

\section{Лumepamypa}

1. Абдулатипов Р.Г. Кавказская цивилизация: самобытность и целостность // Научная мысль Кавказа. 1995. №. 1.

2. Аникеев А.А., Лубский А.В. Теоретические поиски в современной исторической науке и проблема изучения истории Северного Кавказа // Научная мысль Кавказа. 1997. № 3. С. 53

3. Алексеева Е.М. Греческая колонизация Северо-Западного Кавказа. М., 1991.

4. Бетрозов Р. Этническая история адыгов. Нальчик, 1996. С. 170.

5. Гадагатль А.М. Память нации. Генезис эпоса «Нарты». Майкоп, 1997.

6. Гаджиев М.Г. Давудов О.М., Шихсаидов А.Р. История Дагестана с древнейших времен до конца XV в. Махачкала, 1996. С. 177

7. Гадло Л.Б. Этническая история Северного Кавказа. IV-Х вв. Л., 1979.

8. Гасанов М.P. Дагестан и иранский мир. Ереван, 1999.

9. Гедеон, митрополит Ставропольский и Бакинский. История христианства на Северном Кавказе до и после присоединения его к России. М.; Пятигорск, 1992. С. 19.

10. Гмыря Л.Б. Прикаспийский Дагестан в эпоху великого переселения народов. Махачкала, 1993. С. 230.

11. История народов Северного Кавказа с древних времен до конца XVIII в. М., 1988. С.97-99.

12. Кузнецов В.А. Христианство на Северном Кавказе до XV в. Владикавказ, 2002. С. 99- 123.

13. Кцоева Т. У. Кавказский суперэтнос // Эхо Кавказа. 1994. № 2.

14. Новосельцев А.П. Хазарское государство и его роль в истории Восточной Европы и Кавказа. М., 1990.

15. Очерки истории Кубани. С древнейших времен до 1920. Краснодар, 1996. С. 91 107.

16. Патракова В. Ф., Черноус В.В. Русская (российская) цивилизация. Российская историческая политология. Ростов-н/Д., 1998.

17. Пронитейн А.П. Некоторые проблемы отношений на Северном Кавказе в новейшей советской историографии. Развитие феодальных отношений у народов Сeверного Кавказа. Махачкала, 1988. С. 28.

18. Тхагапсоев Х.Г. Лектонический тип коммуникации и проблема цивилизационной идентификации Кавказа // Научная мысль Кавказа. 2001. № 4.

19. Черноус В.В. К вопросу о горской цивилизации. Россия в XIX - нач. XX в. Ростов н/Д., 1992.

20. Черноус В.В. Кавказ: контактная зона цивилизаций и культур. Кавказ: проблемы культурно-цивилизационного развития. Ростов-на-Дону, 2000. См. дискуссию: Научная мысль Кавказа. 2000. № 2. 
21. Черноус В.В. Россия и народы Северного Кавказа: проблемы культурно-цивилизационного диалога // Научная мысль Кавказа. 1999. № 3.

\section{References}

1. Abdulatipov R.G. Kavkazskaya tsivilizatsiya: samobytnost' i tselostnost. Nauchnaya mysl Kavkaza. [Caucasian civilization: identity and integrity. Scientific thought of the Caucasus]. 1995. No. 1. (in Russian).

2. Anikeyev A.A., Lubskiy A.V. Teoreticheskiye poiski v sovremennoy istoricheskoy nauke i problema izucheniya istorii Severnogo Kavkaza. Nauchnaya mysl' Kavkaza. [Theoretical searches in modern historical science and the problem of studying the history of the North Caucasus. Scientific thought of the Caucasus.]. 1997. No. 3. 53 p. (in Russian).

3. Alekseyeva Ye.M. Grecheskaya kolonizatsiya Severo-Zapadnogo Kavkaza. M. [Greek colonization of the Northwest Caucasus. Moscow]. 1991 (in Russian).

4. Betrozov R. Etnicheskaya istoriya adygov. [Ethnic history of Adyghes]. Nalchik. 1996. 170 p. (in Russian).

5. Gadagatl A.M. Pamyat natsii. Genezis eposa «Narty». [The memory of the nation. The genesis of the epic "Nart."]. Maykop, 1997. (in Russian).

6. Gadzhiev M.G. Davudov O.M., Shikhsaidov A.R. Istoriya Dagestana s drevneyshikh vremen do kontsa XV v. [The history of Dagestan from ancient times to the end of the 15th century]. Makhachkala. 1996. 177 p. (in Russian).

7. Gadlo L.B. Etnicheskaya istoriya Severnogo Kavkaza. IV-X vv. L. [tory of the North Caucasus. IV-X centuries. Leningrad]. 1979 (in Russian).

8. Gasanov M.R. Dagestan i iranskiy mir. [Dagestan and the Iranian world]. Yerevan. 1999 (in Russian).

9. Gedeon, mitropolit Stavropol'skiy i Bakinskiy. Istoriya khristianstva na Severnom Kavkaze do i posle prisoyedineniya yego k Rossii. M.; Pyatigorsk. [Gideon, Metropolitan of Stavropol and Baku. The history of Christianity in the North Caucasus before and after its accession to Russia. Moscow; Pyatigorsk]. 1992. 19 p. (in Russian).

10. Gmyrya L.B. Prikaspiyskiy Dagestan v epokhu velikogo pereseleniya narodov. [Caspian Dagestan in the era of the great migration of peoples]. Makhachkala. 1993. 230 p. (in Russian).

11. Istoriya narodov Severnogo Kavkaza s drevnikh vremen do kontsa XVIII v. M. [The history of the peoples of the North Caucasus from ancient times to the end of the 18th century. Moscow]. 1988. pp. 97-99 (in Russian).

12. Kuznetsov V.A. Khristianstvo na Severnom Kavkaze do XV v. [Christianity in the North Caucasus until the 15th century Vladikavkaz,]. Vladikavkaz, 2002. pp. 99-123 (in Russian).

13. Ktsoyeva T. U. Kavkazskiy superetnos. Ekho Kavkaza. [Caucasian superethnos. Echo of the Caucasus].1994. No. 2 (in Russian).

14. Novosel'tsev A.P. Khazarskoye gosudarstvo i yego rol v istorii Vostochnoy Yevropy i Kavkaza. M. [Khazar state and its role in the history of Eastern Europe and the Caucasus. Moscow]. 1990 (in Russian).

15. Ocherki istorii Kubani. S drevneyshikh vremen do 1920. [Essays on the history of the Kuban. From ancient times until 1920]. Krasnodar, 1996. pp. 91-107(in Russian).

16. Patrakova V. F., Chernous V.V. Russkaya (rossiyskaya) tsivilizatsiya. Rossiyskaya istoricheskaya politologiya. Rostov-n/D. [Russian civilization. Russian historical political science. Rostov-on-Don]. 1998 (in Russian). 
17. Proniteyn A.P. Nekotoryye problemy otnosheniy na Severnom Kavkaze v noveyshey sovetskoy istoriografii. Razvitiye feodal'nykh otnosheniy u narodov Severnogo Kavkaza. [Some problems of relations in the North Caucasus in modern Soviet historiography. The development of feudal relations among the peoples of the North Caucasus]. Makhachkala. 1988. 28 p. (in Russian).

18. Tkhagapsoyev K.G. Lektonicheskiy tip kommunikatsii i problema tsivilizatsionnoy identifikatsii Kavkaza. Nauchnaya mysl Kavkaza. [Lectonic type of communication and the problem of the civilizational identification of the Caucasus. Scientific thought of the Caucasus]. 2001. No.4 (in Russian).

19. Chernous V.V. K voprosu o gorskoy tsivilizatsii. Rossiya v XIX - nach. XX v. Rostov $\mathrm{n} / \mathrm{D}$. [To the question of mountain civilization. Russia in the $19^{\text {th }}-$ early $20^{\text {th }}$ century. Rostov-on-Don]. 1992 (in Russian).

20. Chernous V.V. Kavkaz: kontaktnaya zona tsivilizatsiy i kultur. Kavkaz: problemy kul'turno-tsivilizatsionnogo razvitiya. Rostov-na-Donu. 2000. Sm. diskussiyu: Nauchnaya mysl Kavkaza. [Caucasus: contact zone of civilizations and cultures. Caucasus: problems of cultural and civilizational development. Rostov-on-Don. 2000. See discussion: Scientific thought of the Caucasus.]. 2000. No. 2 (in Russian).

21. Chernous V.V. Rossiya i narody Severnogo Kavkaza: problemy kul'turno-tsivilizatsionnogo dialoga. Nauchnaya mysl Kavkaza. [Russia and the peoples of the North Caucasus: problems of cultural and civilizational dialogue. Scientific thought of the Caucasus]. 1999. No. 3 (in Russian).

Опубликовано на русском языке в сборнике: De die in diem. Памяти А.П. Пронштейна (1919-1998). Отв. ред. А.В. Лубский и В.В. Черноус. Р н/Д: Изд-во СКНЦ ВШ. 2004. с. 306-328. На английском языке публикуется впервые.

The article is published in Russian in the scientific works collection: De die in diem. In memory of A.P. Pronstein (1919-1998). Repl. ed. A.V. Lubsky and V.V. Chernous. Rostov-on-Don: Publishing House SKNTs VSh. 2004. pp. 306-328.

In English it is published for the first time. 